\title{
Paideusis
}

\section{School and Society in Victorian Britain: Joseph Payne and the New World of Education (Richard Aldrich)}

\section{Harold Entwistle}

Volume 9, Number 1, 1995

URI: https://id.erudit.org/iderudit/1073251ar

DOI: https://doi.org/10.7202/1073251ar

See table of contents

Publisher(s)

Canadian Philosophy of Education Society

ISSN

0838-4517 (print)

1916-0348 (digital)

Explore this journal

Cite this review

Entwistle, H. (1995). Review of [School and Society in Victorian Britain: Joseph Payne and the New World of Education (Richard Aldrich)]. Paideusis, 9(1), 24-25. https://doi.org/10.7202/1073251ar 
Richard Aldrich. School and Society in Victorian Britain: Joseph Payne and the New World of Education. New York and London: Garland Publishing, Inc., 1995.

This surprisingly readable text is an excellent combination of biography, educational theory, and history of education.

In Victorian England, government funding of education did not begin until 1838 with a derisory grant to voluntary bodies amounting to less than the annual grant for the upkeep of the royal stables. A national system of publicly funded schooling did not materialise until the Education Act of 1870 . Hence, for most of the century, the history of schooling in England is the history of private provision, ranging from schools established by the main religious denominations to Dickensian-type, individual initiatives by persons often barely denominations to Dickensian-type, individequate to supply the educational
literate themselves. Though clearly inadequate
demands of a burgeoning industrial population, these private initiatives did occasionally give birth to innovative contributions to the theory and practice of education. One such was the work of Joseph Payne.

Born in Suffolk in 1808 of humble parentage but of formidable intellectual capacity, Payne was largely self-educated, mastering the classics and several modern languages. He became a teacher in London at the age of nineteen and, ten years later, established his own grammar school at Denmark Hill in partnership with David Fletcher, his mentor, who had been impressed by Payne's work as tutor to his own children. He eventually became a founding member of the College of Preceptors (the first professional association charged with responsibility for licensing schoolmasters under its Royal Charter of 1849) as well as its first professor and the first professor of education in England. He also wrote tirelessly on the theory and practice of education, thus transforming a meagre income from teaching into a comfortable living in a four-storey house at Kildare Terrace in Bayswater.

Several chapters focus on Payne's work as a professor of education and the theory of educational practice which he articulated in his lectures for the College of Preceptors. As a young teacher, he had experienced the work of Jean-Joseph Jacotot, a French educationist, one of the many continental scholars working in the Enlightenment spirit of Helvetius' conclusion that ' $L$ 'éducation peut tout." Jacotot had been a rebel at school which he left at the age of fourteen, having taught himself most of what he knew. He continued as an autcdidact and eventually accumulated academic qualifications in letters, science, and the law. His two basic educational principles were (i) "I believe that God has created the human mind capable of instructing itself alone, and without a master to explain" and (ii) "An enlightened father may teach bis son all that he is ignorant of." This commitment to autodidacticism was, no doubt, attractive to the self-taught Payne who, at twenty-two, authored a fifty-six page pamphlet on Jacotot's ideas. This, his first profitable publication, was the source of his subsequent influence.

Payne's work in education was what we would now call "inclusionist," especially with reference to religion (he was a Congregationalist), class, and gender. Believing that "the mind has properly no sex," he was a critic of the intellectually impoverished schooling usually provided for middle- and upperclass girls with its excessive emphasis upon "accomplishments." He advocated 
a much more rigorous curriculum for girls as against the contemporary preoccupation with music and art. He was an early advocate of co-educational schools and an inspiration to those, especially women, who wanted to open up teacher training to women. With reference to the inequities of social class, he was a vigorous critic of the exclusiveness of the great English public schools like Eton. Though not wanting their abolition, he was an advocate of $r \in$ form, deploring both what he took to be the corruption of their everyday academic and leisure routines, and the privileged access of their graduates to power and influence in the life of the nation. He was equally critical of the elementary schools provided for the majority of working-class children, castigating them for the low attainment of many of their "graduates" and looking to the improvement of popular education through innovations in pedagogy and a raising of the professional standards of teachers. It was this which was his central preoccupation at the College of Preceptors.

Though a practitioner of private education himself, Payne nevertheless recognised the dark side of complete free enterprise in education when "any man or woman-indeed, any boy or girl-however ignorant, however lacking in moral principles or business acumen, could set up a school."

Though Payne's writings were influential in the wider educational milieu in England at the time and, posthumously, in the United States, he has largely been neglected by mainstream historians of education, possibly because he remained an outsider so far as the English political and educational establishments were concerned. Although unusual for a history of education, this book reads like a novel. Alongside the clear and scholarly exposition of Payne's educational theory, the accounts of his early life as a teacher and of his successful marriage and family life, as well as of the politics of his time at the College of Preceptors, are also clearly sketched in a work which will be of interest to anyone concerned with the work of schools and the education of teachers.

Reviewed by Harold Entwistle, Montreal

Joel Spring, Wheels in the Head: Educational Philosophies of Authority, Freedom, and Culture from Socrates to Paulo Freire. New York: McGraw Hill, 1994.

This book gets its title and central organizing principle from the educational ideas of the nineteenth-century libertarian-anarchist Max Stirner (1806-1856). Stirner opposed the rise of mass, state-controlled schooling on the grounds that students end up with "wheels in the head"-that is, ideas that control the individual, rather than the other way around. Stirner, a one-time associate of Karl Marx, applied his critique to radical educational ideologies as well as to those of rising states. Joel Spring builds on Stimer's metaphor to review and critique European philosophies of education ranging from those of Plato to Henri Giroux. The result is a highly accessible textbook that presents a refreshing argument about the liberating purposes of education.

A strength of Spring's work is the elegance of his descriptions of the various philosophies of education. Spring separates description from critique. For example, his first chapter, "Education and the Authoritarian State," reviews 